\title{
Incidence of herpes zoster in patients with altered immune function
}

\author{
S.-Y. Chen · J. A. Suaya $\cdot$ Q. Li • C. M. Galindo • \\ D. Misurski $\cdot$ S. Burstin $\cdot$ M. J. Levin
}

Received: 26 July 2013/ Accepted: 26 October 2013/Published online: 10 November 2013

(c) The Author(s) 2013. This article is published with open access at Springerlink.com

\begin{abstract}
Purpose To estimate the incidence of herpes zoster (HZ) and rates of post-zoster pain in both the total study population and separately in patients with selected conditions/ treatments associated with altered immune function.

Methods The health administrative claims databases for commercially insured, Medicare, and Medicaid populations, together accounting for approximately 51 million insured individuals, were analyzed between 2005 and 2009 in a retrospective cohort study. Incidence of $\mathrm{HZ}$ episodes per 1,000 person-years (PY) was estimated in all study populations as well as within nine potentially immunealtering conditions. Among patients with $\mathrm{HZ}$, the 6-month rate of persistent post-zoster pain was estimated.

Results Analysis of 90.2 million PY at risk revealed that the incidence of $\mathrm{HZ}$ in the total study population was $4.82 /$ 1,000 PY. The incidence of $\mathrm{HZ}$ was highest among patients with bone marrow or stem cell transplant $(43.03 \%)$ followed by solid organ transplant, human immunodeficiency virus infection, and systemic lupus erythematosus [95\% confidence interval (CI) 15.19-17.41\%]. HZ incidence rates were higher among persons on immunosuppressants/ chemotherapy than among non-users. In the total study population, HZ incidence increased with age (18-49 years:
\end{abstract}

S.-Y. Chen $(\bowtie) \cdot$ Q. Li

Evidera, Lexington, MA, USA

e-mail: shih-yin.chen@evidera.com

J. A. Suaya - C. M. Galindo - D. Misurski - S. Burstin

GlaxoSmithKline, Philadelphia, PA, USA

M. J. Levin

University of Colorado Denver, Anschutz Medical Campus,

Aurora, CO, USA
3.37/1,000 PY; 65+ years: 8.43/1,000 PY; $P<0.01)$ and female gender (incidence ratio vs. male $1.39,95 \% \mathrm{CI}$ $1.38-1.40 \%$ ). The 6-month rate of persistent post-zoster pain was $4.29 \%$ (95\% CI 4.22-4.36\%), which was higher in patients with the selected conditions.

Conclusions Despite providing a relatively small fraction of overall $\mathrm{HZ}$ cases, persons with immune function-altering conditions make a large contribution to the societal healthcare burden because they have a higher risk of developing $\mathrm{HZ}$ and persistent post-zoster pain. These risk factors should be considered in $\mathrm{HZ}$ prevention efforts.

Keywords Herpes zoster · Incidence ·

Immune-compromised $\cdot$ Persistent post-zoster pain

\section{Introduction}

Herpes zoster (HZ) is caused by the reactivation in sensory ganglia of latent varicella-zoster virus (VZV), with clinical manifestations of an acute, painful dermatomal vesicular rash that can be followed by persistent post-zoster pain (postherpetic neuralgia) in the same dermatome [1]. HZ results in a significant economic burden in direct healthcare costs [2] and loss of productivity [3, 4]. The occurrence of post-zoster debilitating pain leads to higher direct healthcare costs [5] and adversely impacts the quality of life $[6,7]$.

Population studies in the USA in the early 1990s estimated the incidence of $\mathrm{HZ}$ to be 2.2/1,000 person-years (PY). [8]. In comparison, recent estimates of $\mathrm{HZ}$ incidence in the USA were 3-4/1,000 PY based on data up to 2005 [9-11]. Another USA study reported a trend toward increasing $\mathrm{HZ}$ incidence from 1.7/1,000 PY in 1993 to 4.4/ $1,000 \mathrm{PY}$ in 2006 [12]. A similar observation was found in 
a recent study on the Medicare elderly population between 1991 (9.9/1,000 PY) and 2009 (13.8/1,000 PY) [13].

The onset of $\mathrm{HZ}$ is believed to result from declining VZV-specific cell-mediated immunity (CMI) [14], resulting in patients with conditions or treatments that alter immune function being more susceptible to HZ. The incidence of $\mathrm{HZ}$ has been examined in patients with various conditions or treatment scenarios that alter CMI, including solid organ transplant (SOT) [15-17], cancer [18, 19], human immunodeficiency virus (HIV) infection [20, 21], and autoimmune diseases, such as systemic lupus erythematosus (SLE) [18, 22, 23], rheumatoid arthritis (RA) [18, 24-26], and inflammatory bowel disease (IBD) [18, 27], or together as a group [9]. Although the risk of $\mathrm{HZ}$ has been evaluated in patients with individual conditions, a study that includes a large sample size from the general population enabling the assessment of the comparative risk of $\mathrm{HZ}$ among those conditions will be informative.

There is currently a licensed vaccine to help prevent HZ, as well oral medication that must be taken soon after its onset. Therefore, defining the risk of different populations could be helpful in implementing strategies to decrease the burden of HZ. The objective of this study was to estimate the incidence of $\mathrm{HZ}$ both in the total study population and separately in patients with selected conditions/treatments associated with altered CMI. Among patients with HZ, the rate of persistent post-zoster pain was also evaluated.

\section{Methods}

\section{Data sources}

The analysis was based on data extracted from three administrative medical and pharmacy claims databases on three large populations, namely, (1) commercially insured working adults and their dependents (approx. 30 million) from over 100 large self-insured employers and health plans; (2) Medicare-eligible retirees with Medicare supplemental insurance (approx. 3 million); (3) Medicaid beneficiaries from 12 states (approx. 22 million). The databases contained information on enrollment status, type of healthcare plan, and demographic characteristics, such as age, gender, and region of residence. The following information was captured on pharmacy claims: National Drug Code, dispensing date, quantity, days supplied, and plan- and patient-paid amounts. Details of healthcare service encounters were recorded on the medical claims, including date and place of service, provider type, planand patient-paid amounts, and the international classification of diseases, ninth revision, clinical modification (ICD9-CM) diagnosis and procedure codes across all settings.
Study populations

For inclusion in the study we first selected adults captured the databases aged $\geq 18$ years between 01 January 2005 and 31 December 2009. We excluded individuals from the Medicare population aged $<65$ years and Medicaid enrollees aged $\geq 65$ years, enrollees with dual eligibility of Medicaid and Medicare, and Medicaid enrollees lacking drug coverage because their medical and pharmacy claims were not completely captured in the database. To estimate the incidence of new episodes of $\mathrm{HZ}$, we considered individuals with continuous medical and pharmacy benefits for a period of at least 6 months without any diagnosis of $\mathrm{HZ}$ (ICD-9-CM 053.xx). We also determined separately the incidence of $\mathrm{HZ}$ among patients with the following nine potentially CMI-altering conditions: cancer (excluding skin cancer), HIV infection, bone marrow or stem cell transplantation (BMSCT), SOT, SLE, RA, IBD, psoriasis, and multiple sclerosis (MS). These conditions were identified by ICD-9-CM diagnosis codes and procedures of the medical claims (Appendix Table 5). For cancer, we required at least two medical claims on two separate dates to ascertain a diagnosis. A patient could have multiple conditions and could also contribute to multiple disease populations. The follow-up for the total study population began after the subject had been diagnosed $\mathrm{HZ}$ free for 6 months (index date); the follow-up for the selected disease populations began after the subject had been diagnosed HZ free for at least 6 months and after the first disease-related claim.

Ascertaining incident $\mathrm{HZ}$ cases

Herpes zoster episodes were ascertained based on principal or secondary diagnosis codes of 053.0-053.11, 053.14, 053.19, 053.2x-053.9x. we excluded two post-herpetic neuralgia-related diagnoses $(053.12,053.13)$ to prevent mis-classification of prevalent $\mathrm{HZ}$ cases.

\section{Identification of persistent post-zoster pain}

Patients with $\mathrm{HZ}$ who had at least 6 months continuous enrollment following the incident $\mathrm{HZ}$ diagnosis were assessed for persistent post-zoster pain, which was defined in this study as: (1) a diagnosis of post-herpetic trigeminal neuralgia (ICD-9-CM 053.12) or post-herpetic polyneuropathy (ICD-9-CM 053.13), (2) a diagnosis of $\mathrm{HZ}$ with other nervous system complications (ICD-9-CM 053.19) and more than 30-day supply of medications commonly used for post-zoster pain (Appendix Table 6 ), or (3) unspecified neuralgia, neuritis, or radiculitis (ICD-9-CM 729.2) if it first appeared after the HZ diagnosis. 


\section{Patient characteristics}

Age and gender were assessed at the index date. Chemotherapy treatments among patients with cancer and the administration of immunosuppressants for the selected conditions, except for HIV-infected individuals, were recorded from pharmacy claims and procedure codes in medical claims during the study period (Appendix Table 7).

Statistical analysis

To calculate the incidence of HZ, enrollees were followed from the index date to the end of their continuous enrollment or the date of the incident $\mathrm{HZ}$ episode, whichever came first. The incidence of $\mathrm{HZ}$ was estimated as the number of incident $\mathrm{HZ}$ cases divided by the person-time at risk and presented as number of cases/1,000 PY. The $95 \%$ confidence interval (CI) of incidence was estimated assuming a Poisson distribution.

Incidence of $\mathrm{HZ}$ was reported by age (age categories: 18-49, 50-59, 60-64, 65+ years) and by gender. Since not all selected conditions are immunocompromising when untreated, we also estimated the incidence of $\mathrm{HZ}$ by use of immunosuppressants/chemotherapies. The incident rate ratio (IRR) of $\mathrm{HZ}$ between these mutually exclusive subgroups was reported, and the $95 \%$ CI of IRR was estimated based on the Mantel-Haenszel combined estimate. The Mantel extension of the Armitage-Cochran trend test was used to assess the linear trend in incidence rate from age group $18-49$ to $65+$ years. Among patients with $\mathrm{HZ}$ who had at least 6 months of follow-up, we estimated the 6-month rates of persistent post-zoster pain.
Analyses were conducted using SAS ver. 9.2 (SAS Institute, Cary, NC).

\section{Results}

Characteristics of study sample

There were 218,025,906 enrollees available in the Commercial, Medicare and Medicaid MarketScan database from 2005 to 2009. Among these, 51,022,838 enrollees met the inclusion/exclusion criteria. The mean age of the total study population was 43 years, $54.0 \%$ were female, and the average follow-up was 1.8 years (Table 1$)$. The mean age of the selected conditions was the lowest for patients with HIV infection (mean age 42 years) and the highest for patients with cancer (mean age 60 years). Use of immunosuppressants was most common among patients with SOT $(67.4 \%)$ or BMSCT (58.6\%), followed by RA (49.4\%), SLE (47.0\%), IBD (37.8\%), MS (33.0\%), and psoriasis $(30.3 \%)$. Of the cancer patients, $28.7 \%$ had pharmacy claims for chemotherapies.

\section{Incidence rate of $\mathrm{HZ}$}

In the total study population, 435,378 new cases of $\mathrm{HZ}$ occurred during 90,236,779 PY (Table 2), indicating an incidence of 4.82/1,000 PY (95\% CI 4.81-4.84). The incidence of $\mathrm{HZ}$ among the selected conditions was higher than that in the total study population (Table 2). The incidence of $\mathrm{HZ}$ was highest among patients with BMSCT (43.03/1,000 PY; 95 \% CI 39.96-46.28; ninefold higher

Table 1 Characteristics of the study sample

\begin{tabular}{|c|c|c|c|c|c|c|c|c|c|c|}
\hline \multirow{2}{*}{$\begin{array}{l}\text { Characteristics of the study } \\
\text { sample }\end{array}$} & \multirow{2}{*}{$\begin{array}{l}\text { Number of } \\
\text { persons }\end{array}$} & \multicolumn{2}{|c|}{ Age (years) } & \multicolumn{4}{|c|}{ Age group (\%) } & \multicolumn{2}{|l|}{ Sex } & \multirow{2}{*}{$\begin{array}{l}\text { Use of } \\
\text { immunosuppressants/ } \\
\text { chemotherapy }(\%)\end{array}$} \\
\hline & & Mean & $\mathrm{SD}$ & $\begin{array}{l}18-49 \\
\text { years }\end{array}$ & $\begin{array}{l}50-59 \\
\text { years }\end{array}$ & $\begin{array}{l}60-64 \\
\text { years }\end{array}$ & $\begin{array}{l}65+ \\
\text { years }\end{array}$ & Male & Female & \\
\hline Total study population & $51,022,838$ & 43.1 & 15.8 & 66.0 & 19.2 & 6.2 & 8.6 & 46.0 & 54.0 & N/A \\
\hline $\begin{array}{l}\text { Bone marrow or stem cell } \\
\text { transplant }\end{array}$ & 14,679 & 49.3 & 12.8 & 42.8 & 35.3 & 15.5 & 6.5 & 52.4 & 47.6 & 58.6 \\
\hline Solid organ transplant & 61,189 & 49.7 & 12.5 & 44.5 & 34.0 & 13.1 & 8.4 & 59.2 & 40.8 & 67.4 \\
\hline $\begin{array}{l}\text { Human immunodeficiency } \\
\text { virus infection }\end{array}$ & 121,956 & 41.8 & 10.6 & 76.8 & 18.8 & 3.2 & 1.2 & 69.8 & 30.2 & N/A \\
\hline $\begin{array}{l}\text { Systemic lupus } \\
\text { erythematosus }\end{array}$ & 144,137 & 46.9 & 13.2 & 56.7 & 27.5 & 8.7 & 7.1 & 12.2 & 87.8 & 47.0 \\
\hline Rheumatoid arthritis & 571,555 & 52.7 & 13.9 & 39.4 & 31.8 & 12.7 & 16.1 & 26.7 & 73.3 & 49.4 \\
\hline Cancer & $1,462,356$ & 59.5 & 13.8 & 21.8 & 30.1 & 16.6 & 31.5 & 45.1 & 54.9 & 28.7 \\
\hline Inflammatory bowel disease & 345,565 & 47.0 & 15.0 & 55.5 & 25.1 & 9.2 & 10.2 & 43.5 & 56.5 & 37.8 \\
\hline Multiple sclerosis & 146,261 & 46.3 & 12.1 & 60.1 & 27.5 & 7.2 & 5.2 & 24.1 & 75.9 & 33.0 \\
\hline Psoriasis & 536,770 & 46.2 & 14.7 & 57.2 & 24.8 & 9.1 & 8.9 & 45.6 & 54.4 & 30.3 \\
\hline
\end{tabular}

SD, Standard deviation; N/A, not available 
than that of the total study population). Patients with SOT (17.04/1,000 PY; 95 \% CI 16.23-17.88), HIV (17.41/1,000 PY; $95 \%$ CI 16.81-18.01) and SLE (15.19/1,000 PY; $95 \%$ CI 14.69-15.69) had HZ incidence rates over threefold higher than that in the total study population. The incidence of $\mathrm{HZ}$ in the remaining evaluated conditions was between two- and threefold higher than that of the total study population, including RA (12.24/1,000 PY; $95 \%$ CI 12.02-12.47), cancer $(11.70 / 1,000 \quad \mathrm{PY} ; \quad 95 \%$ CI 11.57-11.83), IBD (9.31/1,000 PY; $95 \%$ CI 9.06-9.56), MS (8.60/1,000 PY; $95 \%$ CI 8.24-8.96) and psoriasis (8.03/1,000 PY; $95 \%$ CI 7.84-8.22).

Incidence rate ratio of $\mathrm{HZ}$ for patients receiving immunosuppressants or chemotherapy

Across the selected conditions, the incidence rates of $\mathrm{HZ}$ were higher among users of immunosuppressants or chemotherapy than among non-users (Table 2). Figure 1 illustrates the IRR with $95 \% \mathrm{CI}$ of users versus non-users. Irrespective of the underlying conditions, users of immunosuppressant or chemotherapy had an approximately $50 \%$ higher risk of $\mathrm{HZ}$ than those without these interventions. The increased risk of $\mathrm{HZ}$ associated with immunosuppressants or chemotherapy was highest among patients with BMSCT (IRR 1.70, $95 \%$ CI 1.45-2.01) and lowest among patients with SLE (IRR 1.46, $95 \%$ CI $1.36-1.56)$.
Incidence rate and rate ratio of $\mathrm{HZ}$ by age and gender

As shown in Table 3, the incidence rate of $\mathrm{HZ}$ in the total study population increased significantly with age $(P<0.01)$ from $3.37 / 1,000$ PY (95\% CI 3.35-3.38) for those aged 18-49 years to $8.43 / 1,000$ PY for those aged $65+$ years $(95 \%$ CI 8.37-8.49). Compared to individuals aged $18-49$ years, the $\mathrm{HZ}$ incidence rate was $91 \%$ higher (IRR 1.91, $95 \%$ CI 1.90-1.92) among those aged 50-59 years, $129 \%$ higher (IRR 2.29, $95 \% \mathrm{CI}$ 2.27-2.31) among those aged 60-64 years and $150 \%$ higher among those aged 65+ years (IRR 2.50, $95 \%$ CI 2.48-2.52). An increasing $\mathrm{HZ}$ incidence with age was also observed among patients with SOT, SLE, RA, cancer, IBD, MS, and psoriasis (all $P<0.01$ ). However, except for persons with psoriasis, the risk of $\mathrm{HZ}$ in these conditions was less influenced by age (as suggested by the IRRs toward the null) than in the total study population. Among patients with BMSCT, there was no significant increase in $\mathrm{HZ}$ incidence with age (Table 3). A decreasing trend of incidence rate was observed among patients with HIV $(P<0.01)$, from 17.8 to $16.0 / 1,000 \mathrm{PY}$ among those aged $<65$ years to 10.70/1,000 PY (95 \% CI 6.62-16.35) in those aged $65+$ years.

In the total study population (Fig. 2), the incidence rate of $\mathrm{HZ}$ among females was $39 \%$ higher than that of males (IRR 1.39, $95 \%$ CI 1.38-1.40). Among patients

Table 2 Incidence of herpes zoster by various immune-altering conditions

\begin{tabular}{|c|c|c|c|c|c|c|c|c|}
\hline \multirow[t]{3}{*}{$\begin{array}{l}\text { Characteristics of the } \\
\text { study sample }\end{array}$} & \multirow{3}{*}{$\begin{array}{l}\text { Number of } \\
\text { herpes zoster } \\
\text { cases }\end{array}$} & \multirow[t]{3}{*}{$\begin{array}{l}\text { Person- } \\
\text { years }\end{array}$} & \multirow[t]{3}{*}{ Incidence $^{\mathrm{a}}$} & \multirow{3}{*}{$\begin{array}{l}95 \% \\
\text { Confidence } \\
\text { interval }\end{array}$} & \multicolumn{4}{|c|}{$\begin{array}{l}\text { Incidence by use of immunosuppressants or } \\
\text { chemotherapy }\end{array}$} \\
\hline & & & & & \multicolumn{2}{|l|}{ Users } & \multicolumn{2}{|l|}{ Non-users } \\
\hline & & & & & Incidence $^{\mathrm{a}}$ & $95 \% \mathrm{CI}$ & Incidence $^{\mathrm{a}}$ & $95 \% \mathrm{CI}$ \\
\hline Total study population & 435,378 & $90,236,779$ & 4.82 & $4.81-4.84$ & N/A & - & N/A & - \\
\hline $\begin{array}{l}\text { Bone marrow or stem } \\
\text { cell transplant }\end{array}$ & 726 & 16,870 & 43.03 & $39.96-46.28$ & 51.50 & $(47.18-56.11)$ & 30.23 & $26.21-34.68$ \\
\hline Solid organ transplant & 1,673 & 98,173 & 17.04 & $16.23-17.88$ & 18.85 & $(17.86-19.89)$ & 12.11 & $10.82-13.52$ \\
\hline $\begin{array}{l}\text { Human } \\
\text { immunodeficiency } \\
\text { virus infection }\end{array}$ & 3,207 & 184,198 & 17.41 & $16.81-18.01$ & N/A & - & N/A & - \\
\hline $\begin{array}{l}\text { Systemic lupus } \\
\text { erythematosus }\end{array}$ & 3,540 & 233,096 & 15.19 & $14.69-15.69$ & 17.85 & $(17.11-18.61)$ & 12.23 & $11.58-12.90$ \\
\hline Rheumatoid arthritis & 11,446 & 934,811 & 12.24 & $12.02-12.47$ & 14.28 & $(13.96-14.61)$ & 9.64 & $9.34-9.94$ \\
\hline Cancer & 29,698 & $2,538,706$ & 11.70 & $11.57-11.83$ & 15.63 & $(15.33-15.93)$ & 10.25 & $10.11-10.40$ \\
\hline $\begin{array}{l}\text { Inflammatory bowel } \\
\text { disease }\end{array}$ & 5,257 & 564,563 & 9.31 & $9.06-9.56$ & 12.07 & $(11.64-12.51)$ & 7.15 & $6.86-7.45$ \\
\hline Multiple sclerosis & 2,146 & 249,551 & 8.60 & $8.24-8.96$ & 11.00 & $(10.35-11.68)$ & 7.05 & $6.64-7.49$ \\
\hline Psoriasis & 6,927 & 862,544 & 8.03 & $7.84-8.22$ & 10.85 & $(10.49-11.23)$ & 6.47 & $6.26-6.68$ \\
\hline
\end{tabular}

HZ, Herpes zoster; CI, confidence interval

${ }^{a}$ Incidence presented as number of cases per 1,000 person-years (PY) 
Fig. 1 Incidence rate ratio of herpes zoster (HZ) for users of immunosuppressants or chemotherapy (users vs. nonusers). BMSCT Bone marrow or stem cell transplant, SOT solid organ transplant, SLE systemic lupus erythematosus, $R A$ rheumatoid arthritis, $I B D$ inflammatory bowel disease, $M S$ multiple sclerosis

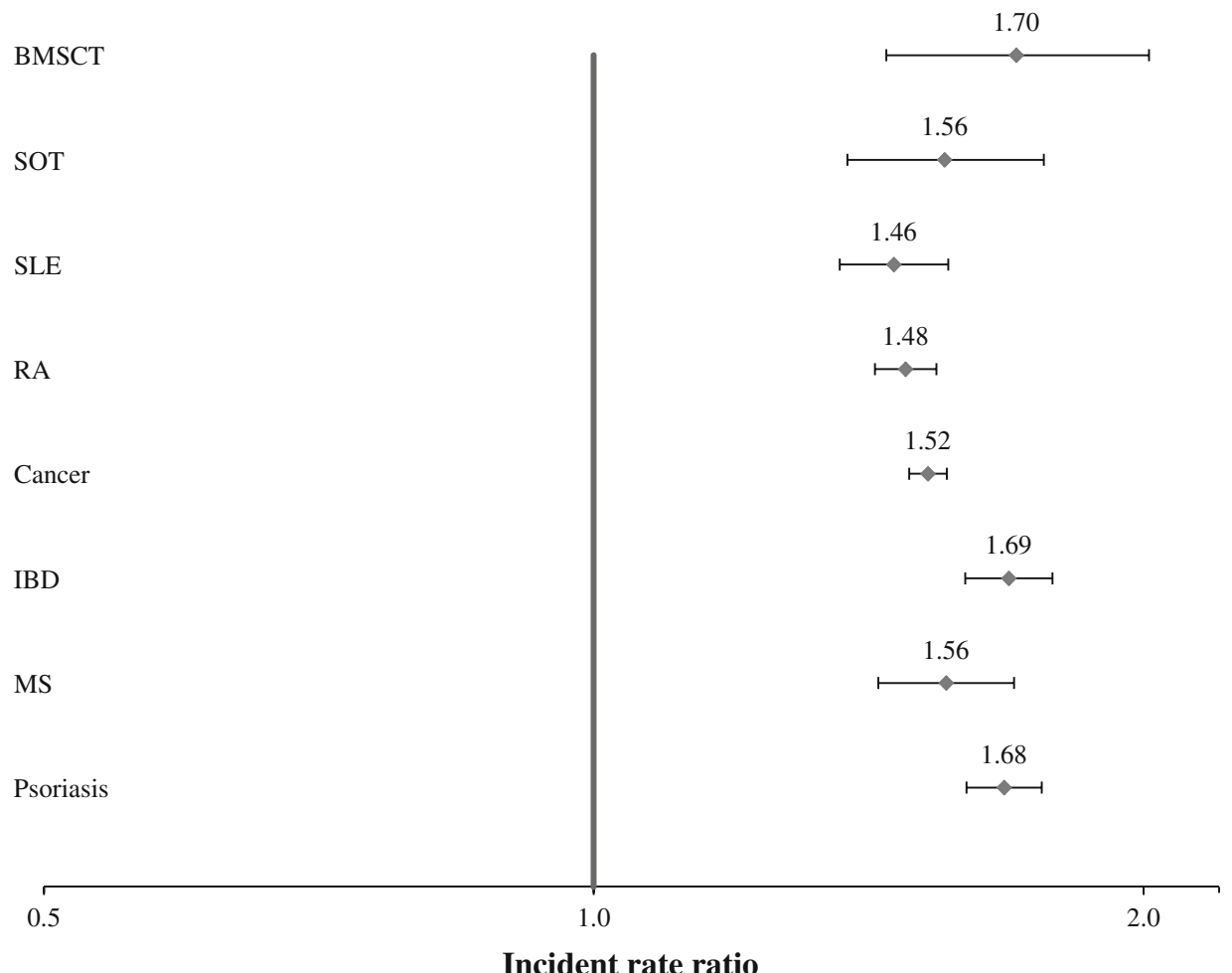

BMSCT: bone marrow or stem cell transplant; SOT: solid organ transplant; SLE: systemic lupus erythematosus; RA: rheumatoid arthritis; IBD: inflammatory bowel disease; MS: multiple sclerosis

Table 3 Incidence and rate ratio of herpes zoster by age group

\begin{tabular}{|c|c|c|c|c|c|c|c|}
\hline \multirow{2}{*}{$\begin{array}{l}\text { Characteristics of the } \\
\text { study population }\end{array}$} & \multicolumn{4}{|c|}{ Incidence $^{\mathrm{a}, \mathrm{b}}(95 \% \mathrm{CI})$} & \multicolumn{3}{|c|}{ Incidence rate ratio $(95 \% \mathrm{CI})$} \\
\hline & $18-49$ years & $50-59$ years & $60-64$ years & $65+$ years & $\begin{array}{l}50-59 \text { vs. } \\
18-49\end{array}$ & $\begin{array}{l}60-64 \text { vs. } \\
18-49\end{array}$ & $\begin{array}{l}65+\text { vs. } \\
18-49\end{array}$ \\
\hline $\begin{array}{l}\text { Total study } \\
\text { population }\end{array}$ & $3.37(3.35-3.38)$ & $6.43(6.40-6.47)$ & $7.71(7.64-7.79)$ & $8.43(8.37-8.49)$ & $1.91(1.90-1.92)$ & $2.29(2.27-2.31)$ & $2.50(2.48-2.52)$ \\
\hline $\begin{array}{l}\text { Bone marrow or } \\
\text { stem cell } \\
\text { transplant }\end{array}$ & $40.20(35.6-45.12)$ & $43.22(38.2-48.65)$ & $50.71(41.8-60.92)$ & $44.73(33.2-58.97)$ & $1.08(0.91-1.27)$ & $1.26(1.01-1.57)$ & $1.11(0.81-1.51)$ \\
\hline $\begin{array}{r}\text { Solid organ } \\
\text { transplant }\end{array}$ & $13.30(12.2-14.43)$ & $19.41(17.9-20.91)$ & $19.76(17.2-22.56)$ & $23.15(19.9-26.76)$ & $1.46(1.30-1.63)$ & $1.49(1.27-1.74)$ & $1.74(1.46-2.06)$ \\
\hline $\begin{array}{l}\text { Human } \\
\text { immunodeficiency } \\
\text { virus infection }\end{array}$ & $17.83(17.1-18.55)$ & $16.42(15.1-17.75)$ & $16.02(12.8-19.78)$ & $10.70(6.62-16.35)$ & $0.92(0.84-1.01)$ & $0.90(0.72-1.11)$ & $0.60(0.37-0.92)$ \\
\hline $\begin{array}{l}\text { Systemic lupus } \\
\text { erythematosus }\end{array}$ & $13.39(12.7-14.04)$ & $15.40(14.5-16.35)$ & $20.01(18.0-22.18)$ & $23.39(21.0-25.91)$ & $1.15(1.07-1.24)$ & $1.49(1.33-1.67)$ & $1.75(1.56-1.96)$ \\
\hline Rheumatoid arthritis & $8.32(8.02-8.63)$ & $12.75(12.3-13.15)$ & $15.31(14.5-16.08)$ & $18.34(17.6-19.04)$ & $1.53(1.46-1.61)$ & $1.84(1.73-1.96)$ & $2.20(2.09-2.32)$ \\
\hline Cancer & $8.39(8.15-8.64)$ & $10.94(10.7-11.17)$ & $13.05(12.6-13.42)$ & $14.14(13.8-14.40)$ & $1.30(1.26-1.35)$ & $1.55(1.49-1.62)$ & $1.68(1.63-1.74)$ \\
\hline $\begin{array}{l}\text { Inflammatory bowel } \\
\text { disease }\end{array}$ & $6.89(6.59-7.19)$ & $11.02(10.5-11.55)$ & $11.67(10.7-12.69)$ & $15.48(14.4-16.53)$ & $1.60(1.50-1.71)$ & $1.69(1.54-1.86)$ & $2.25(2.08-2.43)$ \\
\hline Multiple sclerosis & $6.83(6.42-7.27)$ & $10.75(10.0-11.52)$ & $11.91(10.2-13.75)$ & $12.35(10.4-14.50)$ & $1.57(1.43-1.73)$ & $1.74(1.48-2.04)$ & $1.81(1.51-2.15)$ \\
\hline Psoriasis & $5.28(5.08-5.49)$ & $9.46(9.08-9.86)$ & $13.11(12.2-13.99)$ & $15.39(14.5-16.27)$ & $1.79(1.69-1.90)$ & $2.48(2.30-2.68)$ & $2.91(2.72-3.12)$ \\
\hline
\end{tabular}

${ }^{a}$ Incidence rate presented as number of cases per 1,000 PY

${ }^{\mathrm{b}}$ Linear trend of incidence rate was significant at $P<0.01$ except for bone marrow or stem cell transplant $(P=0.08)$ 
Fig. 2 Incidence rate ratio of $\mathrm{HZ}$ for gender (female vs. male). HIV Human immunodeficiency virus infection

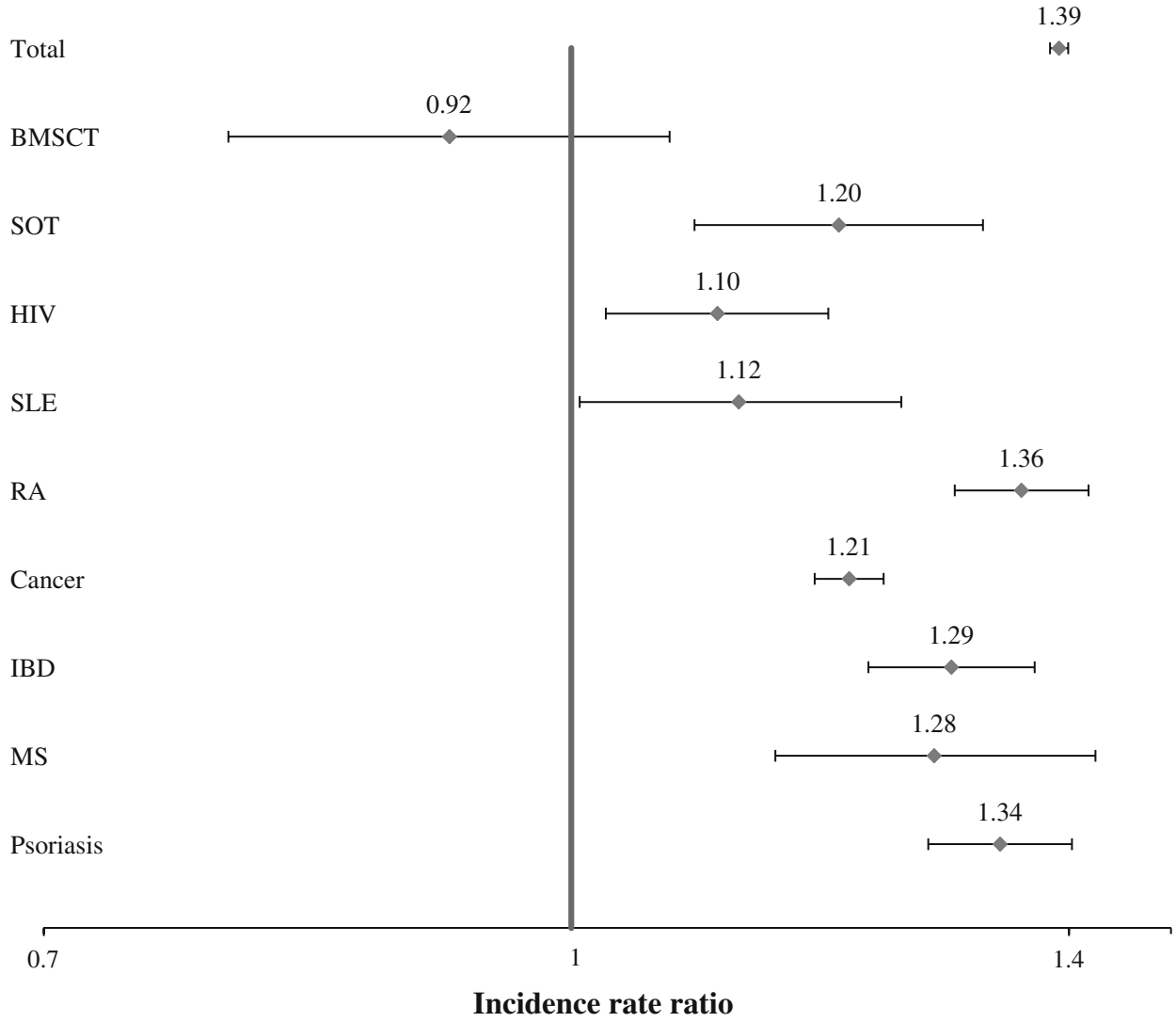

BMSCT: bone marrow or stem cell transplant; SOT: solid organ transplant; HIV: Human immunodeficiency virus infection;

SLE: systemic lupus erythematosus; RA: rheumatoid arthritis; IBD: inflammatory bowel disease; MS: multiple sclerosis

with BMSCT, the HZ incidence rate was not significantly different between females and males (IRR 0.92, $95 \%$ CI 0.79-1.07), but the incidence rate of HZ among females was higher than males in the other conditions, with IRRs ranging from 1.10 (95\% CI 1.02-1.19) in HIV to 1.36 (95\% CI 1.30-1.42) in RA.

Six-month rate of persistent post-zoster pain

There were 322,877 patients who had $>6$ months of continuous enrollment after the onset of $\mathrm{HZ}$ to provide an estimate of the 6-month rates of persistent post-zoster pain (Table 4). Overall, the 6-month rate was $4.29 \%$ (95\% CI 4.22-4.36). In general, the rate was higher among patients with the selected conditions than among the total study population, with BMSCT being the highest $(10.18 \%, 95 \%$ CI 7.83-13.14). For the other selected immunocompromised conditions, the rate of persistent post-zoster pain ranged from $5.08 \%$ among patients with psoriasis $(95 \%$ CI 4.51-5.73) to $7.22 \%$ among patients with RA (95\% CI 6.68-7.80).
Table 4 Six-month rate of persistent post-zoster pain among patients with herpes zoster

\begin{tabular}{|c|c|c|c|}
\hline $\begin{array}{l}\text { Characteristics of the } \\
\text { study population }\end{array}$ & $\begin{array}{l}\text { Herpes } \\
\text { zoster } \\
\text { cases }(n)\end{array}$ & $\begin{array}{l}\text { Rate of persistent } \\
\text { post-zoster related } \\
\text { pain }(\%)\end{array}$ & $95 \% \mathrm{CI}$ \\
\hline $\begin{array}{l}\text { Total study } \\
\text { population }\end{array}$ & 322,877 & 4.29 & $4.22-4.36$ \\
\hline $\begin{array}{l}\text { Bone marrow or } \\
\text { stem cell transplant }\end{array}$ & 501 & 10.18 & $7.83-13.14$ \\
\hline $\begin{array}{r}\text { Solid organ } \\
\text { transplant }\end{array}$ & 1,205 & 6.72 & $5.44-8.28$ \\
\hline $\begin{array}{l}\text { Human } \\
\text { immunodeficiency } \\
\text { virus infection }\end{array}$ & 2,311 & 6.10 & $5.20-7.15$ \\
\hline $\begin{array}{l}\text { Systemic lupus } \\
\text { erythematosus }\end{array}$ & 2,593 & 6.44 & $5.56-7.45$ \\
\hline Rheumatoid arthritis & 8,294 & 7.22 & $6.68-7.80$ \\
\hline Cancer & 21,620 & 7.03 & $6.70-7.38$ \\
\hline $\begin{array}{l}\text { Inflammatory bowel } \\
\text { disease }\end{array}$ & 3,793 & 5.85 & $5.15-6.65$ \\
\hline Multiple sclerosis & 1,563 & 5.57 & $4.53-6.82$ \\
\hline Psoriasis & 4,978 & 5.08 & $4.51-5.73$ \\
\hline
\end{tabular}




\section{Discussion}

The objectives of this study were to estimate the incidence of $\mathrm{HZ}$ and the rate of persistent post-zoster pain within 6 months after the incident $\mathrm{HZ}$ event among adults in the total study population and in those with selected potentially CMI-altering conditions. The relative impact of age, gender and exposure to immunosuppressants or chemotherapies on the incidence of $\mathrm{HZ}$ were also assessed. Using a large nation-wide, multiple-payer U.S. administrative claims database, we found a $\mathrm{HZ}$ incidence of 4.82/1,000 PY for the total study population. A higher incidence was observed associated with female gender and older age. The incidence of $\mathrm{HZ}$ was highest among patients with BMSCT, followed by SOT, HIV, and SLE (43.03-15.19/1,000 PY). The other conditions (RA, cancer, IBD, MS, and psoriasis) had an incident two- to threefold that of the total study population (12.24-8.03/1,000 PY).

As both the incidence of $\mathrm{HZ}$ and the prevalence of risk factors change over time, it is important to assess the most current disease burden. Therefore, this study, derived from 51 million people participating in three different healthcare insurance programs between 2005 and 2009, provides recent data on the epidemiology of $\mathrm{HZ}$ in the USA. Although our study population might not be directly comparable to those of previous studies due to differences in data sources and patient profiles (e.g., age and gender), the higher incidence of $\mathrm{HZ}(4.82 / 1,000 \mathrm{PY})$ observed in our study is consistent with an increasing trend of $\mathrm{HZ}$ incidence over time [8-13].

Within the nine selected conditions, the risk of $\mathrm{HZ}$ was two- to tenfold greater than that seen in the total study population. Although it is difficult to compare absolute values from past studies given the differences in methodology, populations, and time period, our findings are consistent those of earlier studies in that there is a strong effect of immune suppression on the risk of $\mathrm{HZ}[9,18,19,23,25$, 27]. In our study, a more accurate comparison across conditions was possible because patients with these selected conditions were drawn from one large population using the same methodology. Although the majority of $\mathrm{HZ}$ cases occurred among individuals without concurrent alteration in immune function [9, 11], the higher risk of $\mathrm{HZ}$ among patients with altered immune function may be more burdensome from an economic perspective. For example, the higher rate of persistent post-zoster pain observed in these patients will likely require significant healthcare resources and would decrease their productivity and/or quality of life. The comparative risk estimates observed will be informative for the clinicians and payers in targeting populations at a higher risk.

This study also evaluated the comparative effect of various factors across these high-risk conditions.
Consistent with the literature [8-12, 28], our study found a higher risk of $\mathrm{HZ}$ associated with older age in the total study population. Among the selected conditions there was an increasing age trend for HZ except for BMSCT and HIV infection. However, it is worth noting that the absolute risk ratio of $\mathrm{HZ}$ associated with older age in subjects with these conditions is much smaller relative to that in the total study population. This could be because the increased risk associated with older age (mediated by declining VZVspecific CMI) is relatively small compared with that associated with strong immune suppressive effects (on VZV-specific CMI) of the selected diseases and their therapies. The unexpected decreasing risk of $\mathrm{HZ}$ associated with older age in HIV-infected people in our study appears to be driven by the lower risk among patients aged $\geq 65$ years $\quad($ IRR $=0.60$ compared to patients aged 18-49 years; $95 \%$ CI 0.37-0.92). A possible explanation is that older patients who do survive with HIV might be relatively more immune competent and more likely to adhere to treatment than younger patients.

As has been observed in many earlier studies $[9,11,12$, 29-37] — but not all [8, 18, 24, 38, 39]—we found a higher risk of $\mathrm{HZ}$ associated with female gender. No biological explanation has been proposed for this finding. Since we used an administration health claims data, the behavioral differential in health-seeking behavior could not be ruled out. Interestingly, no gender effect in patients with BMSCT was found among our study population, which supports our hypothesis regarding the declining role of other risk factors when a strong immune suppressive effect is present. Our study also confirmed the higher risk associated with immunosuppressants and chemotherapies previously reported [19, 22, 24, 26, 37].

Post-herpetic neuralgia is the most common complication of $\mathrm{HZ}$. The authors of two studies reported that 18-27\% of the adult patients with $\mathrm{HZ}$ in their studies had persistent pain beyond 90 days [11, 40]. This is substantially lower (4.29\% for persistent post-zoster pain) than that in our study. However, the rate of post-zoster pain in this article is not equivalent to that of the more usually reported post-herpetic neuralgia, as we used an algorithm combining diagnostic codes and the utilization of painrelated medications to identify patients likely to have experienced persistent post-zoster pain. Thus, it remains challenging to accurately identify patients experiencing persistent post-zoster pain using the ICD-9-CM diagnosis system, which does not have a specific post-herpetic neuralgia/diagnosis code. Assuming that the disease-specific effects on this algorithm are random (i.e., had the same ability to discriminate this condition between the subgroups even if there was any mis-classification), the relative rates between populations is informative. Our findings of a higher rate of persistent post-zoster pain in the 
evaluated conditions relative to the total study population indicate that persistent post-zoster pain occurs even when the inflammatory response is blunted.

This study has several structural limitations. Diagnoses were derived from administrative billing records which are subject to mis-coding or under-coding and which are not validated against medical charts. Moreover, we only captured health encounters that were reimbursed by the plan. Hence, our data source did not capture the individuals developing HZ/persistent post-zoster pain who did not seek healthcare. Healthcare services or prescription medications paid completely out-of-pocket or by other supplemental insurance were not observed, as were any medicines that had been administered on experimental protocols. Exposure to immunosuppressants, chemotherapies, and pain-related medications could be mis-classified if they were not reimbursed by the health plan or patients did not actually receive the treatment. For example, the use of immunosuppressants appeared to be lower than anticipated in SOT patients; such mis-classification could lead to biased estimates in either direction. The estimated incidence within the conditions with altered immune function were also subject to detection bias, since these patients had more frequent healthcare encounters, which would bias the comparative results between the total study population and the immune-suppressed patients. Finally, our findings might not be generalizable to other populations such as un-insured or veterans.

\section{Conclusions}

In this study we combined three large databases to assess the current epidemiology of HZ. Despite providing a fraction of overall $\mathrm{HZ}$ cases, persons with immune functionaltering conditions have a higher risk of developing $\mathrm{HZ}$ and persistent post-zoster pain. Older age and female gender were also associated with higher risks. These risk factors should be considered in the design of preventive programs that include the use of safe and effective $\mathrm{HZ}$ vaccines.

Acknowledgments We thank Julia Donnelly (freelance publication manager) for her valuable editorial assistance. This study was funded by GlaxoSmithKline. GlaxoSmithKline was involved in all stages of the study conduct and analysis and also took charge of all costs associated with the development and the publishing of the manuscript.

Conflict of interest SYC and QL are employees of Evidera that received funding from GlaxoSmithKline to conduct this study. MJL chairs an adjudication committee for GlaxoSmithKline and receives research support from the company. He serves on an advisory board for Merck, Sharpe \& Dohme and shares intellectual property with that company. JAS, SJB and CMG are employees of the GlaxoSmithKline group of companies and have stock options. DM was an employee of the GlaxoSmithKline group of companies at the time of study development and data analysis.

Open Access This article is distributed under the terms of the Creative Commons Attribution License which permits any use, distribution, and reproduction in any medium, provided the original author(s) and the source are credited.

\section{Appendix}

Tables 5, 6 and 7.

Table 5 International classification of diseases, ninth revision, clinical modification codes of conditions in the study

\begin{tabular}{|c|c|c|}
\hline Disease & $\begin{array}{l}\text { ICD-9-CM } \\
\text { diagnosis codes/ } \\
\text { procedure codes }\end{array}$ & Description \\
\hline \multirow[t]{2}{*}{ Cancer } & $\begin{array}{l}\text { 140.xx-171.xx, } \\
\text { 174.xx-208.xx }\end{array}$ & $\begin{array}{l}\text { Malignant neoplasm } \\
\text { except for other } \\
\text { malignant neoplasm of } \\
\text { skin }(172 . x x, 173 . x x)\end{array}$ \\
\hline & $99.25,99.28$ & $\begin{array}{l}\text { Injection or infusion of } \\
\text { cancer } \\
\text { chemotherapeutic } \\
\text { substance or biological } \\
\text { response modifier as an } \\
\text { antineoplastic agent }\end{array}$ \\
\hline $\begin{array}{l}\text { Human } \\
\text { immunodeficiency } \\
\text { virus infection }\end{array}$ & $042,079.53, \mathrm{~V} 08$ & $\begin{array}{l}\text { Human } \\
\text { immunodeficiency virus } \\
\text { infection }\end{array}$ \\
\hline \multirow{4}{*}{$\begin{array}{r}\text { Solid organ } \\
\text { transplant }\end{array}$} & V42.0, 55.6x & Kidney transplant \\
\hline & $\begin{array}{l}\text { V42.1, 33.6, } \\
37.51\end{array}$ & Heart transplant \\
\hline & $\begin{array}{l}\text { V42.6, 33.5x, } \\
\quad 33.6\end{array}$ & Lung transplant \\
\hline & V42.7, 50.5x & Liver transplant \\
\hline $\begin{array}{l}\text { Bone marrow or } \\
\text { stem cell transplant }\end{array}$ & $\begin{array}{l}\text { V42.81, V42.82, } \\
\quad 41.0 x\end{array}$ & $\begin{array}{l}\text { Bone marrow or stem cell } \\
\text { transplant }\end{array}$ \\
\hline $\begin{array}{l}\text { Rheumatoid } \\
\text { Arthritis }\end{array}$ & 714.xx & Rheumatoid arthritis \\
\hline \multirow{2}{*}{$\begin{array}{l}\text { Inflammatory bowel } \\
\text { disease }\end{array}$} & 555.x & Regional enteritis \\
\hline & $556 . x$ & Ulcerative colitis \\
\hline $\begin{array}{l}\text { Systemic lupus } \\
\text { erythematosus }\end{array}$ & 710.0 & $\begin{array}{l}\text { Systemic lupus } \\
\text { erythematosus }\end{array}$ \\
\hline Multiple sclerosis & $340 . x$ & Multiple sclerosis \\
\hline Psoriasis & $696 . x$ & $\begin{array}{l}\text { Psoriasis and similar } \\
\text { disorders }\end{array}$ \\
\hline
\end{tabular}

ICD-9-CM, International classification of diseases, ninth revision, clinical modification 
Table 6 Medications for persistent post-zoster-related pain

Opioids

Other analgesic medications

Nonsteroidal anti-inflammatory drugs

Anticonvulsants

Lidoderm

Other topical anesthetic

Serotonin-norepinephrine reuptake inhibitors (SNRI)

Tricyclic antidepressants (TCA)
Codeine, hydrocodone, oxycodone, pentazocine, propoxyphene, tramadol, fentanyl, hydromorphone, meperidine, morphine, butorphanol, oxymorphone, levorphanol, methadone

Acetaminophen and combinations, aspirin, and combinations

Ibuprofen and combinations, naproxen and combinations, indomethacin, diclofenac, nabumetone, etodolac, meloxicam, sulindac, piroxicam, oxaprozin, ketoprofen, tolmetin, ketorolac tromethamine, celecoxib, valdecoxib, diflunisal

Gabapentin, pregabalin

Lidocaine patch $5 \%$

Capsaicin-topical

Duloxetine

Amitriptyline and combinations, desipramine, nortriptyline doxepin, imipramine

Table 7 Immunosuppressants and chemotherapies recorded from pharmacy claims and procedure codes during the study period

Immunosuppressants

Chemotherapies
Cyclosporine, tacrolimus, everolimus, sirolimus, azathioprine, mycophenolic acide, mycophenolate mofetil, dexamethasone (oral), hydrocortisone (oral), prednisolone (oral), prednisone (oral), methylprednisolone (oral), triamcinolone (oral), anti-lymphocyte and antithymocyte globulin, basiliximab, canakinumab, certolizumab pegol, daclizumab, golimumab, infliximab, muromonab, natalizumab, omalizumab, rituximab, tocilizuma, ustekinumab, adalimumab, etanercept, abatacept, alefacept, rilonacept

Aldesleukin, alemtuzumab, altretamine, arsenic trioxide, asparaginase, azacitidine, bendamustine, bevacizumab, bexarotene, bleomycin, bortezomib, busulfan, cabazitaxel, capecitabine, carboplatin, carmustine, cetuximab, chlorambucil, cisplatin, cladribine, clofarabine, cyclophosphamide, cytarabine, dactinomycin, dasatinib, daunorubicin, decitabine, denileukin diftitox, docetaxel, doxorubicin, dromostanolone, eculizumab, epirubicin, erlotinib, estramustine, etoposide, everolimus, floxuridine, fludarabine, fluorouracil, gemcitabine, gemtuzumab, ozogamicin, hydroxyurea, ibritumomab, idarubicin, ifosfamide, ifosfamide/ mesna, imatinib, irinotecan, ixabepilone, lomustine, masoprocol, mechlorethamine, megestrol, melphalan, mercaptopurine, methotrexate, methoxsalen, mitomycin, mitotane, mitoxantrone, nelarabine, nilotinib, ofatumumab, oxaliplatin, paclitaxel, panitumumab, pazopanib, pegaspargase, pemetrexed, pentostatin, pipobroman, plicamycin, porfimer, pralatrexate, procarbazine, ranibizumab, rituximab, romidepsin, sorafenib, streptozocin, sunitinib, temozolomide, temsirolimus, teniposide, thioguanine, thiotepa, topotecan, trastuzumab, tretinoin, valrubicin, vinblastine, vincristine, vinorelbine, vorinostat

\section{References}

1. Mueller NH, Gilden DH, Cohrs RJ, Mahalingam R, Nagel MA. Varicella zoster virus infection: clinical features, molecular pathogenesis of disease, and latency. Neurol Clin. 2008;26:675-97.

2. White RR, Lenhart G, Singhal PK, Insinga RP, Itzler RF, Pellissier JM, et al. Incremental 1-year medical resource utilization and costs for patients with herpes zoster from a set of US health plans. Pharmacoeconomics. 2009;27:781-92.

3. Drolet M, Levin MJ, Schmader KE, Johnson R, Oxman MN, Patrick D, et al. Employment related productivity loss associated with herpes zoster and postherpetic neuralgia: a 6-month prospective study. Vaccine. 2012;30:2047-50.

4. Singhal PK, Makin C, Pellissier J, Sy L, White R, Saddier P. Work and productivity loss related to herpes zoster. J Med Econ. 2011;14:639-45.

5. Dworkin RH, White R, O'Connor AB, Hawkins K. Health care expenditure burden of persisting herpes zoster pain. Pain Med. 2008;9:348-53.

6. Katz J, Cooper EM, Walther RR, Sweeney EW, Dworkin RH. Acute pain in herpes zoster and its impact on health-related quality of life. Clin Infect Dis. 2004;39:342-8.
7. Schmader KE, Sloane R, Pieper C, Coplan PM, Nikas A, Saddier $\mathrm{P}$, et al. The impact of acute herpes zoster pain and discomfort on functional status and quality of life in older adults. Clin J Pain. 2007;23:490-6.

8. Donahue JG, Choo PW, Manson JE, Platt R. The incidence of herpes zoster. Arch Intern Med. 1995;155:1605-9.

9. Insinga RP, Itzler RF, Pellissier JM, Saddier P, Nikas AA. The incidence of herpes zoster in a United States administrative database. J Gen Intern Med. 2005;20:748-53.

10. Mullooly JP, Riedlinger K, Chun C, Weinmann S, Houston H. Incidence of herpes zoster, 1997-2002. Epidemiol Infect. 2005;133:245-53.

11. Yawn BP, Saddier P, Wollan PC, St Sauver JL, Kurland MJ, Sy LS. A population-based study of the incidence and complication rates of herpes zoster before zoster vaccine introduction. Mayo Clin Proc. 2007;82:1341-9.

12. Leung J, Harpaz R, Molinari NA, Jumaan A, Zhou F. Herpes zoster incidence among insured persons in the United States, 1993-2006: evaluation of impact of varicella vaccination. Clin Infect Dis. 2011;52:332-40.

13. Hales C, Harpaz R, Joesoef MR, Bialek SR, editors. Increasing incidence of herpes zoster in the U.S. medicare population aged 
65 and older, 1991-2009. San Diego: Infectious Diseases Society of America; 2012.

14. Levin MJ. Immune senescence and vaccines to prevent herpes zoster in older persons. Curr Opin Immunol. 2012;24:494-500.

15. Gourishankar S, McDermid J, Jhangri G, Preiksaitis J. Herpes zoster infection following solid organ transplantation: incidence, risk factors and outcomes in the current immunosuppressive era. Am J Transpl. 2004;4:108-15.

16. Manuel O, Kumar D, Singer LG, Cobos I, Humar A. Incidence and clinical characteristics of herpes zoster after lung transplantation. J Heart Lung Transpl. 2008;27:11-6.

17. Pergam SA, Forsberg CW, Boeckh MJ, Maynard C, Limaye AP, Wald A, et al. Herpes zoster incidence in a multicenter cohort of solid organ transplant recipients. Transpl Infect Dis. 2011;13:15-23.

18. Hata A, Kuniyoshi M, Ohkusa Y. Risk of Herpes zoster in patients with underlying diseases: a retrospective hospital-based cohort study. Infection. 2011;39:537-44.

19. Habel LA, Ray GT, Silverberg MJ, Horberg MA, Yawn BP, Castillo AL, et al. The epidemiology of herpes zoster in patients with newly diagnosed cancer. Cancer Epidemiol Biomarkers Prev. 2013;22:82-90.

20. Blank LJ, Polydefkis MJ, Moore RD, Gebo KA. Herpes zoster among persons living with HIV in the current ART era. J Acquir Immune Defic Syndr. 2012;61:203-7.

21. Jansen K, Haastert B, Michalik C, Guignard A, Esser S, Dupke S, et al. Incidence and risk factors of herpes zoster among hivpositive patients in the german competence network for HIV/ AIDS (KompNet): a cohort study analysis. BMC Infect Dis. 2013;13:372.

22. Borba EF, Ribeiro AC, Martin P, Costa LP, Guedes LK, Bonfa E. Incidence, risk factors, and outcome of Herpes zoster in systemic lupus erythematosus. J Clin Rheumatol. 2010;16:119-22.

23. Chen HH, Chen YM, Chen TJ, Lan JL, Lin CH, Chen DY. Risk of herpes zoster in patients with systemic lupus erythematosus: a three-year follow-up study using a nationwide population-based cohort. Clinics (Sao Paulo). 2011;66:1177-82.

24. McDonald JR, Zeringue AL, Caplan L, Ranganathan P, Xian H, Burroughs TE, et al. Herpes zoster risk factors in a national cohort of veterans with rheumatoid arthritis. Clin Infect Dis. 2009;48:1364-71.

25. Smitten AL, Choi HK, Hochberg MC, Suissa S, Simon TA, Testa MA, et al. The risk of herpes zoster in patients with rheumatoid arthritis in the United States and the United Kingdom. Arthr Rheum. 2007;57:1431-8.

26. Strangfeld A, Listing J, Herzer P, Liebhaber A, Rockwitz K, Richter C, et al. Risk of herpes zoster in patients with rheumatoid arthritis treated with anti-TNF-alpha agents. J Am Med Assoc. 2009;301:737-44.
27. Gupta G, Lautenbach E, Lewis JD. Incidence and risk factors for herpes zoster among patients with inflammatory bowel disease. Clin Gastroenterol Hepatol. 2006;4:1483-90.

28. Pinchinat S, Cebrian-Cuenca AM, Bricout H, Johnson RW. Similar herpes zoster incidence across Europe: results from a systematic literature review. BMC Infect Dis. 2013;13:170.

29. Chapman RS, Cross KW, Fleming DM. The incidence of shingles and its implications for vaccination policy. Vaccine. 2003;21:2541-7.

30. Chidiac C, Bruxelle J, Daures JP, Hoang-Xuan T, Morel P, Leplege A, et al. Characteristics of patients with herpes zoster on presentation to practitioners in France. Clin Infect Dis. 2001;33:62-9.

31. Fleming DM, Cross KW, Cobb WA, Chapman RS. Gender difference in the incidence of shingles. Epidemiol Infect. 2004; $132: 1-5$.

32. Gauthier A, Breuer J, Carrington D, Martin M, Remy V. Epidemiology and cost of herpes zoster and post-herpetic neuralgia in the United Kingdom. Epidemiol Infect. 2009;137:38-47.

33. Opstelten W, Van Essen GA, Schellevis F, Verheij TJ, Moons KG. Gender as an independent risk factor for herpes zoster: a population-based prospective study. Ann Epidemiol. 2006;16:692-5.

34. Oxman MN, Levin MJ, Johnson GR, Schmader KE, Straus SE, Gelb LD, et al. A vaccine to prevent herpes zoster and postherpetic neuralgia in older adults. N Engl J Med. 2005;352:2271-84.

35. Russell ML, Schopflocher DP, Svenson L, Virani SN. Secular trends in the epidemiology of shingles in Alberta. Epidemiol Infect. 2007;135:908-13.

36. Toyama N, Shiraki K. Society of the Miyazaki Prefecture D. Epidemiology of herpes zoster and its relationship to varicella in Japan: a 10-year survey of 48,388 herpes zoster cases in Miyazaki prefecture. J Med Virol. 2009;81:2053-8.

37. Zhang J, Xie F, Delzell E, Chen L, Winthrop KL, Lewis JD, et al. Association between vaccination for herpes zoster and risk of herpes zoster infection among older patients with selected immune-mediated diseases. JAMA. 2012;308:43-9.

38. Di Legami V, Gianino MM, Ciofi degli Atti M, Massari M, Migliardi A, Tomba GS, et al. Epidemiology and costs of herpes zoster: background data to estimate the impact of vaccination. Vaccine. 2007;25:7598-604.

39. Scott FT, Johnson RW, Leedham-Green M, Davies E, Edmunds WJ, Breuer J. The burden of herpes zoster: a prospective population based study. Vaccine. 2006;24:1308-14.

40. Scott FT, Leedham-Green ME, Barrett-Muir WY, Hawrami K, Gallagher WJ, Johnson R, et al. A study of shingles and the development of postherpetic neuralgia in East London. J Med Virol. 2003;70:S24-30. 